\title{
Awareness on the Effects of Periodontal Diseases on the General Health of Individuals with Systemic Diseases and Determination of Influential Factors
}

\author{
Sistemik Hastalığı Bulunan Bireylerin Genel Sağıkta Periodontal \\ Hastalıkların Etkisi Konusunda Farkındalık ve Etkileyen \\ Faktörlerin Belirlenmesi
}

(D) Gülhan Kocaman

Karabük University Faculty of Dentistry, Department of Periodontology, Karabük, Turkey

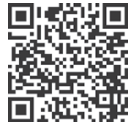

Keywords

Periodontal disease, systemic disease, rheumatoid arthritis, diabetes, cardiovascular diseases

Anahtar Kelimeler

Periodontal hastalık, sistemik hastalık, romatoid artrit, diyabet, kardiyovasküler hastalıklar

Received/Geliş Tarihi : 20.05 .2019

Accepted/Kabul Tarihi : 09.08.2019

doi:10.4274/meandros.galenos.2019.75537

Address for Correspondence/Yazışma Adresi: Gülhan Kocaman MD,

Karabük University Faculty of Dentistry, Department of Periodontology, Karabük, Turkey Phone : +90 5057705425

E-mail :dentist25@hotmail.com

ORCID ID: orcid.org/0000-0002-8920-2391

(C) Meandros Medical and Dental Journal, Published by Galenos Publishing House.

This is article distributed under the terms of the

Creative Commons Attribution NonCommercial 4.0

International Licence (CC BY-NC 4.0).

\begin{abstract}
Objective: This study aimed to investigate the level of awareness regarding the effect of systemic diseases on periodontal diseases among individuals with systemic diseases.

Materials and Methods: This descriptive study was carried out on 200 patients with systemic diseases (100 men, 100 women; age, 18-65 years) who presented to the internal medicine, rheumatology, and cardiology departments and oral health polyclinics. A questionnaire including 15 questions about personal information, socio-demographic characteristics and level of awareness about periodontal diseases was administered to the participants. They were asked to select among the three responses, "Agree", "Disagree" or "Undecided", for each statement.

Results: This study found that the level of knowledge of approximately $68 \%$ of the participants regarding the relationship between systemic diseases and periodontal diseases was not sufficient, and their level of awareness was significantly low. The level of knowledge was significantly affected by educational level, frequency of tooth brushing and previous oral hygiene education $(p<0.05)$.

Conclusion: Periodontal diseases are in Two-way interaction with some systemic diseases. An increase in the level of knowledge will positively affect the course of the disease and will improve the quality of life. Therefore, patients with systemic diseases should be given oral hygiene training in both primary health care centres and oral health centres.
\end{abstract}

Öz

Amaç: Bu çalışma, sistemik hastalığı bulunan bireylerin periodontal hastalıkların sistemik hastalıklar üzerine etkileri konusunda bilinç düzeylerini ve etkileyen faktörleri incelemek amacıyla planlanmıştır.

Gereç ve Yöntemler: Tanımlayıcı tipte planlanan çalışma, dahiliye, romatoloji ve kardiyoloji ve ağız diş sağ ığı polikliniklerine başvuran, sistemik hastalığı bulunan, yaş aralığı 18-65 olan, 100 erkek 100 kadın olmak üzere toplam 200 hasta üzerinde yürütülmüştür. Hastalara kişisel bilgi ve sosyo-demografik özellik içeren sorular 
ve diş eti hastalıkları hakkında bilinç düzeylerini değerlendirmeyi amaçlayan 15 ifade içeren anket uygulanmıştır ve bu ifadelere "Katılıyorum", "Katılmıyorum" veya "Kararsızım" şeklinde yanıtlamaları istenmiş̧tir.

Bulgular: Yapılan çalışmada katılımcıların sistemik hastalık diş eti hastalıkları arasındaki ilişki konusunda \%68'inin bilgi düzeylerinin yeterli olmadığı, farkındalığın anlımlı derecede düşük olduğu, periodontal hastalık konusunda bilgi düzeyinin ise eğitim düzeyi, diş fırçalama sıklığı ve daha önce alınmış oral hijyen eğitiminden anlamlı düzeyde etkilendiği saptanmıştır $(p<0,05)$.

Sonuç: Periodontal hastalıklar bazı sistemik hastalıklarla çift yönlü etkileşim içerisindedirler. Bu bilgi düzeyinin artması hastalığın seyrini olumlu etkileyecek ve bireyin yaşam kalitesini artıracaktır. Bu nedenle sistemik hastalığı olan bireylere oral hijyenin genel sağlık üzerine etkileri konusunda eğitim verilmesi bireyin yaşam kalitesini artıracaktır.

\section{Introduction}

Periodontal diseases (gum disease) are diseases that result in destruction of hard and soft tissue that progress with a number of host-microorganism reactions initiated by dental plaque microorganisms (1). Destruction of tissues takes place by two mechanisms, either directly or indirectly. The response of individuals to periodontal pathogens varies. This is because periodontal diseases vary in each individual in terms of progression, severity and time of onset (2). These individual differences may also be associated with family history of systemic disease. Genetic factors, environmental factors and systemic diseases are the factors that affect and change the pathogenesis of periodontal diseases and the response of the host to treatment (3). On the other hand, it has been suggested that periodontal diseases are infectious and chronic in nature, and thus, they may alter local and systemic host response to pathogens which affect the general health of the individual and the course of some systemic diseases (4). Cardiovascular diseases, diabetes and rheumatoid arthritis are the leading causes of systemic diseases where interrelationships are mostly observed. It is emphasized that periodontal diseases, particularly severe and advanced ones, are related to diabetes and cardiovascular system diseases (3-5).

There is a relationship between rheumatoid arthritis and periodontal diseases because they both are chronic inflammatory diseases, there is soft and hard tissue destruction in the course of both diseases, and high proinflammatory cytokine levels are present in both $(6,7)$. The relationship between periodontal diseases and cardiovascular system diseases is defined as occurrence of systemic inflammation, which starts as a local inflammatory attack (8).

It is thought that periodontitis and diabetes share a common pathogenesis with increasing inflammatory response on the local and systemic levels, and they are known to have reciprocal relations (9). Diabetes may cause some complications such as disorders of blood circulation in various organs and tissues, disorders of oxygen diffusion in local tissues, thickening of capillary and basal membranes, inability to remove metabolic wastes and defects in cellular and humoral immune responses (10). As these complications are similar to the pathophysiology of periodontal diseases, periodontitis is considered to be a complication of diabetes, and there is a two-way relationship between diabetes and periodontitis $(11,12)$. Additionally, advanced glycation end-products formed after high blood sugar levels are thought to play a role in development of the chronic complications of diabetes (13).

The aim of this study was to evaluate the awareness level about periodontal diseases among patients who have systemic diseases such as cardiovascular disease, diabetes and rheumatoid arthritis and have been treated and followed up at cardiology, internal medicine and rheumatology outpatient clinics along with the factors effecting this awareness.

\section{Materials and methods}

The descriptive study was initiated with the approval of the Non-interventional Clinical Studies Ethics Committee (date: 01/11/2017, decision no: 10/9) of Karabük University. Informed consent was obtained from individuals who voluntarily participated in the study after explaining the aims and benefits of the study and their roles in the study.

The study included a total of 200 patients, 100 males and 100 females, diagnosed with diabetes, rheumatoid arthritis or cardiovascular system disorders (coronary heart disease, acute myocardial infections, stroke-related diseases such as coronary heart disease, acute myocardial infections and stroke). 
In this study, a questionnaire containing 15 items was prepared based on a literature review. The questionnaire included socio-demographic characteristics, oral and dental health characteristics and statements aimed at measuring the level of knowledge of the participants on periodontal diseases. The items in the questionnaire were presented to the participants in the form of a complete sentence, which could be true or false, and the participants were asked to answer these statements as "Agree" or "Disagree". The correct answers were scored as 1, and the incorrect and incomplete ones were graded as 0 . The total score for each participant was obtained based on their cumulative score across 15 questions. The knowledge level and awareness of those who scored less than half, i.e. 0-7, were considered insufficient.

\section{Statistical Analyses}

Percentages, One-way ANOVA, student's t-test and Tukey's mean separation test were used to analyze the data obtained in the study. The Minitab and Microsoft Excel programs were used for all statistical analyses. A $p$-value of $<0.05$ was accepted as the cut off value for statistical significance.

\section{Results}

The mean age of 200 individuals (100 females, 100 males) included in the study was $56.13 \pm 9.8$ (Minimum:19, Maximum:77). Among these individuals, $120(60 \%)$ were married and $80(40 \%)$ were single. It was determined that 126 individuals (63.0\%) had primary education, 37 (18.5\%) were high school graduates, and 37 (18.5\%) were university graduates. It was observed that 21 individuals (10.5\%) had low, 118 individuals (59.0\%) had moderate and 61 individuals (30.5\%) had high income levels. Among the patients, 130 (65.0\%) had never smoked, $22(11.0 \%)$ had smoked but quitted recently, and $48(24.0 \%)$ were smoking. When the systemic disease statuses of the individuals were examined, we observed that 62 individuals (31.0\%) had cardiovascular system diseases, 111 individuals (55.5\%) had diabetes, and 27 participants (13.5\%) had rheumatoid arthritis (Table 1 ).

It was found that 52 patients (26.0\%) brushed their teeth several times a day, 104 patients (52.0\%) brushed their teeth several times a week, and 44 patients $(22.0 \%)$ brushed their teeth several times a month. 98 patients $(49.0 \%)$ reported that they did not have enough knowledge about oral and dental health, while 102 patients (51.0\%) reported that they had sufficient knowledge about oral and dental health. A total of $130(65.0 \%)$ participants had prostheses (Table 2).

A total of 13 items about the relationship between periodontal diseases and systemic diseases were directed to the participants (Table 3 ). Only 45 participants (22.5\%) responded correctly to the statement "Gum disease affects the overall body". One-hundred participants $(50.0 \%)$ did not have any knowledge, and (Table 3) 67 (33.5) participants selected the correct response for the statement "gum disease increases the number of microbes in the body by means of blood".

When the scores obtained from questioning the participants knowledge on the relationship of periodontal disease-systemic disease were analyzed, it was determined that the ratio of participants who scored 0-7 points was $68 \%$ (Table 4 ).

\begin{tabular}{|c|c|c|c|}
\hline \multicolumn{2}{|l|}{ Age $56.13 \pm 9.8(\min : 19, \max : 77)$} & $\mathbf{n}$ & $\%$ \\
\hline \multirow{2}{*}{ Gender } & Female & 97 & 48.5 \\
\hline & Male & 103 & 51.5 \\
\hline \multirow{2}{*}{ Marital status } & Married & 120 & 60.0 \\
\hline & Single & 80 & 40.0 \\
\hline \multirow{3}{*}{ Education level } & Primary & 126 & 63.0 \\
\hline & High school & 37 & 18.5 \\
\hline & University & 37 & 18.5 \\
\hline \multirow{3}{*}{ Income level } & Low $(<1000)$ & 21 & 10.5 \\
\hline & $\begin{array}{l}\text { Medium } \\
(1000-2000)\end{array}$ & 118 & 59.0 \\
\hline & High (>2000) & 61 & 30.5 \\
\hline \multirow{3}{*}{ Smoking } & Never & 130 & 65.0 \\
\hline & Quitted & 22 & 11.0 \\
\hline & Smoker & 48 & 24.0 \\
\hline \multirow{3}{*}{ Presence of systemic disease } & $\begin{array}{l}\text { CV system } \\
\text { disease }\end{array}$ & 62 & 31.0 \\
\hline & Diabetes & 111 & 55.5 \\
\hline & $\begin{array}{l}\text { Rheumatoid } \\
\text { arthritis }\end{array}$ & 27 & 13.5 \\
\hline \multicolumn{2}{|l|}{ Total } & 200 & 100 \\
\hline \multicolumn{4}{|c|}{ Min: Minimum, max: Maximum, CV: Cardiovascular } \\
\hline
\end{tabular}


When the total score of periodontal diseasessystemic diseases knowledge statements were compared to the other variables, it was determined that the level of knowledge was not affected by gender. Nevertheless, the total score was significantly affected by the level of oral hygiene education, highest education level and tooth brushing frequency. The awareness of the participants was found to be significantly low (Table 5).

Table 2. Oral and dental health information of patients

\begin{tabular}{|l|l|l|l|}
\hline \multirow{4}{*}{ Teeth brushing frequency } & Several times a day & $\mathbf{n}$ & 26.0 \\
\cline { 2 - 4 } & Several times a week & 52 & 52.0 \\
\cline { 2 - 4 } Did you have oral hygiene training? & Several times a month & 104 & 22.0 \\
\hline \multirow{3}{*}{ Do you have a dental prosthesis? } & No & 44 & 49.0 \\
\cline { 2 - 4 } & Yes & 98 & 51.0 \\
\hline \multirow{3}{*}{ How often do you clean your prosthesis? } & No & 102 & 35.0 \\
\cline { 2 - 4 } & Yes & 70 & 65.0 \\
\cline { 2 - 4 } & Several times per day & 130 & 13.5 \\
\cline { 2 - 4 } & Several times a week & 27 & 40.0 \\
\cline { 2 - 4 } & Several times per month & 23 & 11.5 \\
\cline { 2 - 4 } & None & 70 & 35.0 \\
\hline
\end{tabular}

Table 3. Distribution of the responses to items on knowledge of periodontal disease-systemic disease

\section{Periodontal disease knowledge statements}

Gum disease increases the number of microbes in the body by means of blood

Gum disease increases the risk of heart disease

Gum disease increases the risk of joint rheumatism

Gum disease causes microbial infiltration into the blood and exacerbates existing diseases

Gum disease is more common in diabetic patients

Existing gum disease is exacerbated in diabetic patients

Blood clotting may increase in gum disease

More attention should be devoted to oral care as the body defenses decrease in diabetics

Since gum disease triggers heart disease, more attention should be paid to oral care

As gum diseases increase the number of microbes in the blood, patients with rheumatism should pay more attention to oral care

Those with cardiovascular diseases should pay more attention to oral care for general health

Gum disease affects the overall body

Gum disease lays the ground for cardiovascular diseases

Smoking also worsens gum disease similar to heart disease

If the food residue in the tooth does not get brushed off regularly, it causes gum disease

Total

\section{\begin{tabular}{|l|l|l|} 
Agree $\mathbf{n}(\%)$ & Disagree $\mathbf{n}(\%)$ & Undecided $\mathbf{n}(\%)$
\end{tabular}}

\begin{tabular}{|l|l|l|}
\hline $67(33.5)$ & $33(16.5)$ & $100(50.0)$ \\
\hline $61(30.5)$ & $41(20.5)$ & $98(49.0)$ \\
\hline $44(22.0)$ & $44(22.0)$ & $112(56.0)$ \\
\hline $93(39.5)$ & $27(13.5)$ & $94(47.0)$ \\
\hline $93(46.5)$ & $24(12.0)$ & $83(41.5)$ \\
\hline $42(21.0)$ & $36(18.0)$ & $122(61.0)$ \\
\hline $110(55.0)$ & $18(9.0)$ & $72(36.0)$ \\
\hline $72(36.0)$ & $30(15.0)$ & $98(49.0)$ \\
\hline $70(35.0)$ & $34(17.0)$ & $96(48.0)$ \\
\hline $69(34.5)$ & $39(19.5)$ & $92(46.0)$ \\
\hline $45(22.5)$ & $29(14.5)$ & $126(63.0)$ \\
\hline $58(29.0)$ & $29(14.5)$ & $113(56.5)$ \\
\hline $125(62.5)$ & $9(4.5)$ & $66(33.0)$ \\
\hline $55(27.5)$ & $29(14.5)$ & $126(63.0)$ \\
\hline & & $200(100)$ \\
\hline & & \\
\hline & & \\
\hline
\end{tabular}


Table 4. Distribution of periodontal disease-systemic disease relationship knowledge scores

\begin{tabular}{|l|l|l|l|}
\hline \multirow{2}{*}{ Cumulative points gathered from gum disease knowledge statements } & $\mathbf{n}$ & $\%$ \\
\cline { 2 - 4 } & 0-7 Points & 136 & 68.0 \\
\cline { 2 - 4 } & 8-15 Points & 64 & 32.0 \\
\hline
\end{tabular}

Table 5. Analyses of the periodontal diseases-systemic diseases knowledge statements in the context of the other variables

\begin{tabular}{|c|c|c|c|c|c|}
\hline & & $\mathbf{n}$ & Mean \pm SD & $\mathbf{t}$ & $\mathbf{p}$ \\
\hline \multirow{2}{*}{ Gender } & Female & 97 & $5.49 \pm 4.6$ & \multirow{2}{*}{0.45} & \multirow{2}{*}{0.83} \\
\hline & Male & 103 & $13.6 \pm 3.7$ & & \\
\hline \multirow{2}{*}{ Did you have previous oral hygiene training? } & No & 98 & $4.26 \pm 4.3$ & \multirow{2}{*}{13.52} & \multirow{2}{*}{$<0.001 *$} \\
\hline & Yes & 102 & $6.52 \pm 4.5$ & & \\
\hline \multirow{2}{*}{$\begin{array}{l}\text { Cumulative points gathered from gum diseases } \\
\text { knowledge statements }\end{array}$} & 0-7 Point & 136 & $2.82 \pm 2.5$ & \multirow{2}{*}{-21.80} & \multirow{2}{*}{$<0.001 *$} \\
\hline & 8-15 Point & 64 & $10.92 \pm 2.4$ & & \\
\hline & & $\mathbf{n}$ & Mean \pm SD & f & p \\
\hline \multirow{3}{*}{ Education level } & Primary & 127 & $4.86 \pm 4.7$ & \multirow{3}{*}{3.84} & \multirow{3}{*}{$<0.001 *$} \\
\hline & High school & 37 & $5.21 \pm 3.6$ & & \\
\hline & University & 36 & $7.63 \pm 3.9$ & & \\
\hline \multirow{3}{*}{ Tooth brushing frequency } & Several times a day & 52 & $7.7 \pm 4.4$ & \multirow{3}{*}{10.48} & \multirow{3}{*}{$<0.001 *$} \\
\hline & Several times a week & 104 & $4.8 \pm 4.4$ & & \\
\hline & Several times a month & 44 & $4.0 \pm 3.6$ & & \\
\hline
\end{tabular}

\section{Discussion}

Taking necessary measures for periodontal diseases in the presence of systemic diseases and preventing them from occurring are important goals for public health (14). Furthermore, oral and dental health is an important factor that directly affects the quality of life and satisfaction of the individual, which should not be considered apart from general systemic health (15). We evaluated the knowledge and awareness levels of individuals with rheumatoid arthritis, diabetes and cardiovascular diseases (coronary heart disease, acute myocardial infections, and stroke) in the light of the literature.

We determined that the participants' levels of knowledge and awareness were significantly low. The relationship between periodontal diseases and systemic diseases such as heart diseases, diabetes, rheumatoid arthritis and pregnancy complications is known. However, it is evident that it is necessary to disseminate this information, and failure to do so may adversely affect public health $(16,17)$.
In their study, Granados-Principal et al. (18) reported that periodontal diseases are have a reciprocal relationship with cardiovascular diseases, and physicians of both branches should work together considering the common risk factors in these two types of diseases. Kinane and Lowe (19) found a common set of predisposing factors for periodontal diseases and cardiovascular diseases in a study that targeted underlying factors of both diseases, and they argued that both disorders affected each other. In our study, it was evident that the rate of correct answers to the knowledge-related statements was low, and the level of knowledge and awareness of the participating individuals about the bidirectional relationship between periodontal status and cardiovascular disease was quite low.

In their comparative study, Özkan et al. (20) reported that the patients with rheumatoid arthritis had a higher risk of periodontal disease compared to healthy individuals. In order to promote motivation for periodontal and oral care in rheumatoid arthritis 
patients, they suggested informing patients regarding the bidirectional relationship between rheumatoid arthritis and periodontal health. They also emphasized the use of mechanical cleaning assistive devices such as electric toothbrushes, irrigation devices, chlorhexidine and fluorinated mouthwashes for oral care. In our study, it was determined that patients with rheumatoid arthritis had low levels of knowledge about periodontal diseases, and they did not have sufficient knowledge and awareness about the existence of a relationship between existing systemic disorders and periodontal health. Potempa et al. (21) stated that patients with rheumatoid arthritis should be given a detailed protective dentistry service and emphasized the importance of acquisition and maintenance of periodontal health in such patients.

Poyrazoğlu et al. (22) concluded that all diabetic patients should have regular oral examinations, especially periodontal examinations, and patients and their families should be educated in this regard. Acıpınar et al. (23) stated that there is a bidirectional relationship between periodontitis and diabetes, and they trigger each other. Thus, they emphasized that treatment of periodontal disease should be a part of diabetes treatment.

In our study, the level of awareness of diabetic patients about periodontal health knowledge and the bidirectional relationship between periodontal health and diabetes were investigated, and their awareness and knowledge levels were found to be very low. In parallel with the literature, we think that patients and their families should be informed more on oral and periodontal health and directed to routine dental checkups.

However, as limitations of our study, the low level of education in Turkish society and random formation of individuals in the studied population caused a disproportionate distribution of education levels. Additionally, since there were no conditions for oral findings and dental indices of the patients at internal medicine and cardiology outpatient clinics, their levels of knowledge and current oral statuses could not be discussed. Considering these limitations, it is useful to carry out further studies with larger samples.

\section{Conclusion}

Oral health disorders, periodontal diseases and general systemic diseases are very common health problems in Turkish society, and they affect quality of life negatively. Oral health, especially periodontal health, has a two-way interaction with some systemic diseases. As evident in this study, the awareness levels of the participants on the relationship between periodontal diseases and systemic diseases and relationship between periodontal diseases and general health were low. In patients with these types of systemic disease, training should be given on periodontal diseases, and appropriate treatments should be provided when necessary. Dentists and medical doctors should work in coordination in management of this bidirectional relationship.

\section{Ethics}

Ethics Committee Approval: The descriptive study was initiated with the approval of the NonInterventional Clinical Studies Ethics Committee of Karabük University (decision no: 10/9, date: 01/11/2017).

Informed Consent: Informed consent was obtained from individuals who voluntarily participated in the study after explaining the aims and benefits of the study and their roles in the study.

Peer-review: Externally peer-reviewed.

Financial Disclosure: The authors declared that this study received no financial support.

\section{References}

1. Pischon N, Pischon T, Kröger J, Gülmez E, Kleber B-M, Bernimoulin $\mathrm{J}-\mathrm{P}$, et al. Association among rheumatoidarthritis, oral hygiene, and periodontitis. J Periodontol 2008; 79: 979-86.

2. White SC, Pharoah MJ. Systemic Diseases Manifested in the Jaws. In: Rudolph P, Alvis K, editors. Oral Radiology: Principles and Interpretation. 5th Ed. St Louis: C.V. Mosby Co., 2009. p.597614.

3. Dumitrescu AL. Occurence of self-reported systemic medical conditions in patients with periodontal disease. Rom J Intern Med 2006; 44: 35-48.

4. Bahekar AA, Singh S, Saha S, Molnar J, Arora R. The prevalence and incidence of coronary heart disease is significantly increased in periodontitis: a meta-analysis. Am Heart J 2007; 154: 830-7.

5. Mealey BL, Ocampo GL. Diabetes mellitus and periodontal disease. Periodontol 2000 2007; 44: 127-53.

6. Rutger Persson G. Rheumatoid arthritis and periodontitis-inflammatory and infectious connections. Review of the literature. J Oral Microbiol 2012; 4.

7. Kaur S, White S, Bartold PM. Periodontal disease and rheumatoid arthritis: a systematic review. J Dent Res 2013; 92: 399-408.

8. Soory M. Chronic periodontitis as a risk marker for systemic diseases with reference to cardiometabolic disorders: 
common pathways in their progression. Immunology and Immunogenetics Insights 2010; 2: 7-21.

9. Lloyd DR, Marples J. Serum Fructosamine Does Reflect Levels of Glycated Serum Albumin in Insulin- Dependent Diabetics. Ann Clin Biochem 1988; 25: 432-4.

10. Karande AM, Khandeparkar R, Vergeese CS. Inter-relationship between diabetes mellitus and periodontal disease based on their molecular mechanisms. J Adv Med Dent Scie Res 2017; 5: 24-32.

11. Jindal A, Agarwal N, Sakalle D, Dushyant P. Diabetes mellitus and periodontitis-a two way relationship. PJSR 2017; 10: 91-4.

12. Preshaw PM, Alba AL, Herrera $D$, Jepsen $S$, Konstantinidis A, Makrilakis K, et al. Periodontitis and diabetes: a two-way relationship. Diabetologia 2012; 55: 21-31.

13. Singh R, Barden A, Mori T, Beilin L. Advanced glycation endproducts: A review. Diabetologia 2001; 44: 129-46.

14. Aydıntuğ YS, Şençimen M, Bayar GR, Mutlu I, Gülses A. The frequency of various systemic diseases in adult patients admitting to the department of oral and maxillofacial surgery outpatient clinic. Gülhane Medical Journal 2010; 52: 7-10.

15. Li X, Kolltveit KM, Tronstad L, Olsen I. Systemic diseases caused by oral infection. Clin Microbiol Rev 2000; 13: 547-58.
16. Illhan B, Çal E, Dündar N, Güneri P, Dağhan Ş. Oral health-related quality of life among institutionalized patients after dental rehabilitation. Geriatr Gerontol Int 2014; 15: 1151-7.

17. Külekçi G, Gökbuget A. The Effect of Oral Microbiota on General Health. Ankem Derg 2009; 23: 137145.

18. Granados-Principal S, El-Azem N, Quiles JL, Perez-Lopez P, Gonzalez A, Ramirez-Tortosa $M$, et al. Relationship between cardiovascular risk factors and periodontal disease: current knowledge. Cardiovascular Risk Factors 2012; 1: 193-216.

19. Kinane DF, Lowe GD. How periodontal disease may contribute to cardiovascular disease. Periodontology 2000, 2000; 23: 121-6.

20. Özkan Y, Alpaycı M, Özkan M, Hız Ö, Bozan N. Romatoid artritli hastalarda periodontal hastalık şiddeti: karşılatırmalı çalışma. Nobel Med 2015; 11: 54-8.

21. Potempa J, Mydel P, Kozie J. The case for periodontitis in the pathogenesis of rheumatoid arthritis. Nature Reviews Rheumatology, 2017; 13: 606.

22. Poyrazoğlu Ş, Saka N, Yeşil S, Kafaoğlu M, Fıratlı E. Periodontal disease in children with type 1 diabetes mellitus. The Journal of the Child 2009; 9: 25-8.

23. Acıpınar Ş, Karşıyaka Hendek M, Olgun Erdemir E. Periodontitis ve Diabetes Mellitus: Çift Yönlü İlişki. Kırıkkale Üniversitesi Tıp Fakültesi Dergisi 2017; 19: 103-13. 